https://doi.org/10.11646/zootaxa.4370.4.2

http://zoobank.org/urn:lsid:zoobank.org:pub:3FA9C3EB-816F-4567-8C90-7B9D3BABE9BF

\title{
Unrealized diversity in an urban rainforest: A new species of Lygosoma (Squamata: Scincidae) from western Sarawak, Malaysia (Borneo)
}

\author{
BENJAMIN R. KARIN ${ }^{1,2,6}$, ELYSE S. FREITAS ${ }^{3}$, SAMUEL SHONLEBEN ${ }^{4}$, L. LEE GRISMER ${ }^{5}$, \\ AARON M. BAUER ${ }^{1} \&$ INDRANEIL DAS ${ }^{4}$ \\ ${ }^{1}$ Department of Biology, Villanova University, 800 Lancaster Avenue, Villanova, PA 19085, USA. \\ E-mail:benkarin@berkeley.edu,aaron.bauer@villanova.edu \\ ${ }^{2}$ Museum of Vertebrate Zoology, 3101 Valley Life Sciences Building, University of California, Berkeley, CA 97420, USA. \\ ${ }^{3}$ Sam Noble Oklahoma Museum of Natural History, University of Oklahoma, 2401 Chautauqua Avenue, Norman, OK 73072, USA. \\ E-mail: efreitas@ou.edu \\ ${ }^{4}$ Institute of Biodiversity and Environmental Conservation, Universiti Malaysia Sarawak, 94300 Kota Samarahan, Sarawak, \\ Malaysia.E-mail: idas@unimas.my,mrkodok@hotmail.co.uk \\ ${ }^{5}$ Department of Biology, La Sierra University, 4500 Riverwalk Parkway, Riverside, California, 92515-8247 USA. \\ E-mail: lgrismer@lasierra.edu \\ ${ }^{6}$ Corresponding author
}

\begin{abstract}
We collected two specimens of an undescribed species of Lygosoma from pitfall traps in an urban rainforest in Kuching and from the base of a forested hill in western Sarawak, East Malaysia. The new species is diagnosable from all south-east Asian congeners by morphological characters, and most closely resembles Lygosoma herberti from the Thai-Malay Peninsula. The new species shows substantial molecular divergence from its closest relatives in two protein-coding genes, one mitochondrial (ND1) and one nuclear (R35) that we sequenced for several south-east Asian congeners. We describe the new species on the basis of this distinct morphology and genetic divergence. It is the third species of Lygosoma known from Borneo, and highlights the continuing rise in lizard species diversity on the island. In addition, the discovery of this species from a small urban rainforest underscores the importance of preserving intact rainforest areas of any size in maintaining species diversity.
\end{abstract}

Key words: Borneo; Sarawak; Scincidae; Lygosoma samajaya new species

\section{Introduction}

The island of Borneo, the third-largest island in the world, is one of the most biodiverse regions on earth, yet it suffers from several decades of severe deforestation that has impacted most of the rainforest on the island, and particularly the lowlands (Bryan et al. 2013; Gaveau et al. 2014). Borneo has been designated as a biodiversity hotspot (Mittermeier et al. 1998; Myers et al. 2000), defined as a place with exceptional diversity under threat by anthropogenic activity. Understanding the diversity of the region is important for generating local interest and implementing effective conservation strategies (Gadgil et al. 1993).

Despite having a long history of zoological (e.g., de Bruyn et al. 2014; Inger 1966; Wallace 1869) and especially herpetological research (see Das 2004a), it is clear that the lizard diversity on Borneo remains underestimated, particularly for scincids and gekkonids. This is especially evident when compared to 33 recent species described from the much smaller adjacent Peninsular Malaysia (see Grismer et al. 2016). Currently, 36 species of geckos and 51 species of skinks are recognized to occur on Borneo (Uetz \& Hošek 2017). In the past year alone (2016-2017), three new skink species including Tytthoscincus batupanggah Karin, Das \& Bauer 2016, Tytthoscincus leproauricularis Karin, Das \& Bauer 2016, and Tropidophorus sebi Pui, Karin, Bauer \& Das, 2017, and one new gecko species, Cnemaspis leucura Kurita, Nishikawa, Matsui, \& Hikida, 2017, have been described from specimens recently collected from (mostly south-western) Sarawak. This has resulted in an increase of six 